\title{
Hospital Management Innovation in Public Services in Regional Public Hospitals Lanto Dg. Pasewang Jeneponto District
}

\author{
Hijrah Lail ${ }^{1}$, Aam Azatil Isma ${ }^{2}$ \\ ${ }^{1,2}$ Universitas Muhammadiyah Sinjai \\ Email: hijrahumsi@gmail.com
}

\begin{abstract}
Services in the health sector are one of the most needed forms of service by the community. This study aims to describe the process of public service innovation carried out by the Hospital Management and to identify the factors that influence public service innovation implemented by the Jeneponto District Hospital. This research is also expected to provide input (suggestions) in the process of implementing innovation in public services to create quality services and improve the performance of the Regional General Hospital Lanto Dg. Pasewang. The research method used is descriptive qualitative. Researchers will explain the research problem in detail, namely the innovation process and the factors that influence it. Data collection was obtained through direct observation of the object of research and in-depth interviews with relevant sources, namely, Hospital Management in public services at the Lanto Dg. Pasewang Regional General Hospital led by the Hospital Director, and Heads of fields and communities involved directly feel the hospital service innovation. The results of this study indicate that Hospital Management Innovations in Public Services at the Lanto Dg. Pasewang Regional General Hospital Jeneponto Regency, have made public service innovations in improving services to the patients
\end{abstract}

Keywords: Innovation, hospital management, public services

\section{INTRODUCTION}

(Undang-Undang Nomor 23 Tahun 2014 Tentang Pemerintahan Daerah), has given autonomy authority to regions to develop their potential, including in terms of public services in the health sector. Theoretically, the presence of regional autonomy will increase regional authority and discretion to formulate and implement policies that are more in line with regional needs and community demands (Alarabiat et al., 2020; Ayuningtyas et al., 2020; Langkai et al., 2019; Wenda \& Akib, 2015)

Services in the health sector are one of the most needed forms of service by the community (Amin \& Nasharuddin, 2013; Kalaja et al., 2016; Rexhepi \& Shrestha, 2011; Rose et al., 2004). This cannot be separated from the needs of citizens to stay healthy. Adequate health services are the foundation of society and become one of the basic needs besides food and education. The community hopes to get the implementation of health services in a responsible, safe, quality, equitable and non-discriminatory manner so that the rights of patients as recipients of these health services can be protected. As a consequence, apart from improving hospital management, the hospital apparatus also needs to be continuously improved. One of the efforts that can be done is through public service innovation.

A hospital as a health service subsystem provides two types of services for the community, namely health services and administrative services (Hartwell et al., 2016; Johns et al., 2010; Zarei et al., 2012). Hospitals need to implement a management system that is oriented towards community satisfaction (Blondell \& Azadfard, 2013; Guptill, 2005; Handayani et al., 


\section{Jurnal Administrare: Jurnal Pemikiran Ilmiah dan Pendidikan Administrasi Perkantoran \\ Volume 8 Issue 1, January-June 2021. Pages 43-48}

2017). For the Regional General Hospital Lanto Dg. Pasewang, having to create superior performance or performance Excellence is a major factor that the hospital management must strive for. There are many ways that hospital managers can do to create superior performance, including through innovation in providing good service and accurate medical action and quality management mechanisms of course.

Jeneponto as one of the districts in Indonesia which are still in the 3T regional category needs to carry out a process of innovations in its public organize This is an effort to provide community satisfaction in providing services. One of them is the public bureaucracy that is in the process of implementing innovation in the field of health services, namely the Management of the Lanto Dg. Pasewang Regional General Hospital, Jeneponto Regency, must make an innovation in terms of service. The closure of services in May 2019 at the Regional General Hospital Lanto Dg. Pasewang, Jeneponto Regency, the cause is due to the many complaints of the community who complain that hospital services are paralyzed due to depleted drug stocks, resulting in many people unable to access health services and patients who while in This problem arises because hospital management does not work so that it becomes a national public consumption which is very embarrassing because there is no service. Treatment was referred to the Bantaeng Regional Hospital and the Takalar Regional Hospital. After the closure of services at the Regional General Hospital Lanto Dg. Pasewang, Jeneponto Regency, the Regent of Jeneponto immediately removed the hospital director.

The dismissal of the director of the Lanto Dg. Pasewang Regional Hospital was stated in letter number 163/2019 / concerning the dismissal of dr. Iswan Sanabi from the position of Echelon IIIa Administrator within the scope of the temporary Jeneponto Regency Government who replaced him, namely drg. Bustamin, who was listed in letter number 800/470 / BPKSDM / V / 2019 as the executor of the task, was then officially inaugurated on 2/6/2019 after about one month of serving as the executor of the Lanto Dg. Pasewang Regional General Hospital in Jeneponto Regency. In this study, it is interesting to reveal after the closure of the Lanto Regional General Hospital with Pasewang under the leadership of the new Hospital Director, the management of the Lanto Regional General Hospital with Pasewang is demanded to make innovations in providing health services. to achieve efficiency in improving the quality and performance of hospital personnel.

\section{METHOD}

This type of research is a descriptive qualitative approach Moleong in (Arhas \& Suprianto, 2020), by describing that qualitative methods are research that intends to understand existing phenomena by discussing Hospital Management Innovations in Public Services. The data collection techniques used to obtain information in this study included: in-depth interviews, observation techniques, and document the implementation of this research from official sources that can be accounted for.

The data analysis technique in this study uses the Mile and Huberman model $\mathrm{n}$ (Arhas \& Suprianto, 2020) which suggests that data analysis in qualitative research is carried out interactively and continuously and until it is complete so that the data is saturated. Activities in data analysis are data reduction, display data, conclusion, and verification (Sugiono, 2011:334 in Eri Bonggasau; 2015). This interactive analysis technique is carried out in the following ways: (1) Data reduction, namely the selection process, focusing on simplification, abstracting, 
and transforming the rough data that appears in the field. In data reduction, the researcher translates, classifies, directs, removes unnecessary, and organizes the data in such a way that finally conclusions can be drawn and verified by the researcher. (2) Data display or data presentation is presenting a set of structured information which gives the possibility of drawing conclusions and taking action. Data presentation can be done in the form of brief descriptions, charts, relationships between categories, low charts, and the like. By displaying the data, it will be easier to understand what is going to happen, to plan the next work.

\section{RESULT AND DISCUSSION}

Lanto Dg. Pasewang Regional General Hospital is one of the health service facilities with basic service standards and referrals from various health centers in the Jeneponto Regency which aims to create a network between other health facilities, which are currently accredited Type C according to the Decree of the Minister of Health of the Republic of Indonesia / IV / 2008 dated April 15, 2008. Regional General Hospital Lanto Dg. Pasewang was built on an area of 4.5 hectares which is located on Jln. H.M.Ishak Iskandar, Empoang Selatan Village, according to Operational Permit Number: 115/1797/2014 dated 17 November 2016. With the number of personnel as of September 2020 as many as 245 civil servants / ASN and 841 noncivil servant workers with various disciplines.

One example of public sector innovation practice in the field of health services is the Application Innovation carried out by the Lanto Dg. Pasewang Regional General Hospital in Jeneponto Regency, the LDP SMART Hospital application stands for "Lanto Dg. Pasewang Hospital" and is a breakthrough in services. health to break the long queue of patients or their families to get medical records. Previously, patients or patients' families queued for hours at the service counter and we're not certain when to get medical record services, but with this innovation, they no longer need to queue long at the Hospital's general service administration.

Maximum Service Innovation: RSUD LATOPAS JENEPONTO LAUNCHING Latest CT SCAN RSUD Lanto Dg. Pasewang is known as a hospital that has reliable and professional medical personnel, and to support service maximization, Dr.Bustamin as Director, since his leadership has continued to make innovations, to create quality and satisfying complete health services for patients, appreciation as a form of the quality improvement of services for the latest computed tomography scan radiology tools is now available at Lanto Dg. Pasewang Hospital.

In general, a CT (computerized tomography), this examination uses a computer to create cross-sectional images of the bones, blood vessels, and soft tissue present in the person's bodygraph). The scan is a procedure that combines a series of X-ray images that are taken from different sides of a person's body. This procedure shows more detailed images than ordinary Xrays, and we launched this medical device technology (CT SCAN) on Thursday, 23 July 2020, "Said Drg. Bustamin, Director of Lanto Hospital Dg. Pasewang, Jeneponto Regency".

Continued Drg.Bustamin, The main target of servants at Lanto Dg. Pasewang, of course, to improve work professionalism in preparing, determining, and implementing basic service levels and specialist service levels to support the improvement of service quality, in general, for the success of maximum and quality services in the hospital, it must be supported by well-established human resources, as well as complete various facilities. other healthsupporting facilities and infrastructure, "Patient healing and satisfaction is our pride which is always loyal to provide quality health services. 


\section{6 | Jurnal Administrare: Jurnal Pemikiran Ilmiah dan Pendidikan Administrasi Perkantoran \\ Volume 8 Issue 1, January-June 2021. Pages 43-48}

The public service innovation for the LDP SMART Hospital application was carried out by the Lanto Dg. Pasewang Hospital is not a single innovation that only occurs in the service department. More than that, this innovation is a series of other forms of innovations that tend to be integral, but in some cases, the process is not linear. This means that there are several innovations at the level of the organization's internal management that must be done to realize these service innovations.

Every innovation that is carried out can be the influence of certain forms of innovation, or one form of innovation can influence the emergence of other forms of innovation. The emergence of various forms of innovation in the Lanto Lanto Dg. Pasewang Regional General Hospital organization is also very much influenced by external organizations and the community as service users where these actors are also influenced by environmental factors. Likewise, the impact, which is felt not only for service users but also for the organization itself. In other words, the innovation of LDP SMART Hospital is not an activity that occurs in isolation rooms, but there is involvement between actors in certain areas that contribute to the emergence of these innovative practices.

Lanto Dg. Pasewang Regional General Hospital Management Service Innovation Jeneponto Regency with the help of the LDP SMART Hospital Application. Patients make it easier to register if they want treatment and to avoid long queues. The LDP SMART Hospital application makes the functions of the care department more concentrated on professional medical care/services, the billing function is carried out by the finance department while the giving of discounts is the authority of the board of directors. Medical personnel do not need to think about the financial capacity of patients and do not differentiate between services to patients because medical personnel will be given the same incentive for the same action, regardless of who the medical services are given. This pattern is proven to positively affect the performance of medical personnel, which in turn will improve the overall quality of hospital services.

If the hospital management wants the LDP SMART Hospital application to be implemented successfully in the hospital, then the following must be considered: development Master Plan, a development blueprint must be well designed starting from the initial survey to the end of implementation, what needs to be considered is the involvement of the experience factor in building the same work, as well as the participation of all parts of the organization in the success of the Management Information System to be built. This master plan will become a reference for making a system for an unlimited period; integrated, with the integration between all parts of the organization into one unit, will make innovation run efficiently and effectively so that constraints such as redundancies, re-entry, and data inconsistencies can be avoided, in the hope that application users get benefits that can be felt directly, changes in work patterns from manual to application will have good and bad effects for medical staff and patient; development Team, the team that builds Hospital Service Management Innovation must be expert and experienced in their field, which in this case is an IT expert in mastering networks, hardware, and software (mastering the PHP programming language, MySQL database, oracle

Changes in work culture from manual to automation. This cultural change is not easy to do, in fact, it often disrupts the migration process from manual to computer-based automation. Leaving ingrained work habits (work comfort zone) and willing to learn to adapt to the new system, is not easy. Sometimes it takes courage, assertiveness, and mutual agreement between leaders and employees. 


\section{Discussion}

This amendment project regulates the main authority and duties of the Hospital Management in the context of implementing the Hospital Management Information System. Furthermore, the Head of the Hospital, one of the main duties and functions of the hospital, is to be able to monitor all service reports in the hospital both in the inpatient, outpatient, supporting, and hospital finances through the Hospital Management Information System application.

The Hospital Management Information System that previously existed still had many shortcomings in its application, namely the absence of a bridging system with other health applications, and a lack of inpatient modules, where the hospital should have a SIMRS that was able to do a bridging system with other health service applications and completeness. service modules according to the hospital flow. Furthermore, the scope of limitations in the Change Project area is due to the time limit in this change project ( 2 months), the series of activities that will be carried out sequentially during this Change Project with the scope of scope, namely: approval and support of facilities and policies from the leadership; the availability of an open source-based hospital management information system application; the issuance of a Decree on the Work Team for the change project and the making of the Hospital Management Information System application; there is a statement of stakeholder support; the existence of patient data entry training, hospital service rates, Human Resources on the Hospital Management Information System application; availability of Hospital Management Information System; monitoring and evaluation of change project activities.

An organizational information system that will strive to be more competitive and efficient which in turn adds value to obtaining, changing, and changing information to improve decision making, improve organizational performance in achieving organizational goals. An effective information system provides users with accurate, timely, and relevant information so that it can be used for decision making. In decision making, both in day-to-day operations and in future strategic planning. The decision-making process must be based on timely and appropriate data and information so that decisions are made on target. Information obtained from data processing and data processing is carried out by information systems with the support of information technology (Susanto \& Meiryani, 2019).

\section{CONCLUSION}

Based on the results of the research, the researcher can conclude that the new Hospital Director for approximately one year in office has made Hospital Management Innovations in public services at the Lanto Dg Pasewang Regional General Hospital, Jeneponto Regency. The innovation made is making the LDP SMART Hospital application, the purpose of this application is to maximize outpatient services, this is done to avoid long queues at the registration section at the Polyclinic.

\section{REFERENCES}

Alarabiat, A., Soares, D., \& Estevez, E. (2020). Determinants of citizens' intention to engage in government-led electronic participation initiatives through Facebook. Government Information Quarterly, 101537. https://doi.org/https://doi.org/10.1016/j.giq.2020.101537

Amin, M., \& Nasharuddin, S. Z. (2013). Hospital service quality and its effects on patient satisfaction and behavioural intention. Clinical Governance. https://doi.org/10.1108/CGIJ- 
48 | Jurnal Administrare: Jurnal Pemikiran Ilmiah dan Pendidikan Administrasi Perkantoran Volume 8 Issue 1, January-June 2021. Pages 43-48

05-2012-0016

Arhas, S. H., \& Suprianto, S. (2020). The Effectiveness of 6M Implementation at Artebo MSME. Jurnal Ad'ministrare, 6(2), 249-256.

Ayuningtyas, D., Fachry, A., Sutrisnawati, N. N. D., \& Munawaroh, S. (2020). Medical tourism as the improvement of public health service: A case study in Bali and West Nusa Tenggara. Enfermería Clínica, 30, 127-129. https://doi.org/https://doi.org/10.1016/j.enfcli.2020.06.029

Blondell, R. D., \& Azadfard, M. (2013). Hospital management. In Addressing Unhealthy Alcohol Use in Primary Care. https://doi.org/10.1007/978-1-4614-4779-5_18

Guptill, J. (2005). Knowledge management in health care. In Journal of Health Care Finance. https://doi.org/10.4018/978-1-61520-670-4.ch023

Handayani, P. W., Hidayanto, A. N., Pinem, A. A., Hapsari, I. C., Sandhyaduhita, P. I., \& Budi, I. (2017). Acceptance model of a Hospital Information System. International Journal of Medical Informatics. https://doi.org/10.1016/j.ijmedinf.2016.12.004

Hartwell, H. J., Shepherd, P. A., Edwards, J. S. A., \& Johns, N. (2016). What do patients value in the hospital meal experience? Appetite. https://doi.org/10.1016/j.appet.2015.09.023

Johns, N., Hartwell, H., \& Morgan, M. (2010). Improving the provision of meals in hospital. The patients' viewpoint. Appetite. https://doi.org/10.1016/j.appet.2009.10.005

Kalaja, R., Myshketa, R., \& Scalera, F. (2016). Service Quality Assessment in Health Care Sector: The Case of Durres Public Hospital. Procedia - Social and Behavioral Sciences. https://doi.org/10.1016/j.sbspro.2016.11.082

Langkai, J. E., Akib, H., Musa, I. C. T., \& Naharia, U. (2019). The Implementation of Environment-Based Program (PBL) To increase community welfare in Manado City. ODISHA JOURNAL OF SOCIAL SCIENCE, 19.

Rexhepi, L., \& Shrestha, P. (2011). Lean Service Implementation in Hospital. Rheumatology.

Rose, R. C., Uli, J., Abdul, M., \& Ng, K. L. (2004). Hospital service quality: A managerial challenge. International Journal of Health Care Quality Assurance. https://doi.org/10.1108/09526860410532784

Susanto, A., \& Meiryani. (2019). Database management system. International Journal of Scientific and Technology Research. https://doi.org/10.5120/179-310

Undang-Undang Nomor 23 Tahun 2014 tentang Pemerintahan Daerah, (2014).

Wenda, W. L., \& Akib, H. (2015). Pembangunan Ekonomi dalam Era Otonomi Daerah di Kabupaten Pegunungan Bintang, Indonesia. Jurnal Ilmiah Ilmu Administrasi Publik: Jurnal Pemikiran Dan Penelitian Administrasi Publik, 5(1), 43-51.

Zarei, A., Arab, M., Froushani, A. R., Rashidian, A., \& Tabatabaei, S. M. G. (2012). Service quality of private hospitals: The Iranian Patients' perspective. BMC Health Services Research. https://doi.org/10.1186/1472-6963-12-31 